\title{
World music, authenticity and Africa: Reading Cesaria Evora and Ali Farka Toure
}

\author{
Anandam Kavoori
}

\section{Introduction}

In this essay, I engage with the complex set of sonic connections known as 'World Music'. The section on 'Framing World Music/The Global Postmodern/Authenticity' outlines some key elements in how World Music can be theoretically framed - as a specific kind of text, anchored in conditions of global post modernity and characterized by a defining discourse -that of 'authenticity'. This is followed by a biographical/textual account of two major global music stars from Africa - Cesaria Evora (Cape Verde) and Ali Farka Toure (Mali) - with a focus on examining how their biographical and textual imprint illustrates the different ways in which the discourse of 'authenticity' is mobilised within World Music/The Global Postmodern. Finally, the concluding section summarises some general ideas about authenticity and World Music. My overall goals are to engage with the specific textual elements that make up the sonic construct of World Music, steering clear of popular discourse about it. ${ }^{\mathrm{i}}$

\section{Framing World Music ii/ The Global Postmodern/Authenticity}

Aubert (2007:1) offers a beginning point for understanding music as something central to meaning in a culture, rather than mere 'fluff' - light entertainment for the illiterate and the bored: 'If music has its own place in all reflections on culture, it does so by the stakes it represents. Music is indeed never insignificant. It is simultaneously a strong and unifying means of communication and a revealer of identity within the abundance of models that characterize society. We identify ourselves with music we like because it corresponds to our sensibility and vision of the world; we draw apart from other music when it is foreign to our affinities and fails to "speak" to us. Through its content music is always a bearer of meanings.'

Aubert (2007:1) adds that 'if Plato could write that "the music and literature of a country cannot be altered without major political and social changes" that is because the music he was referring to was at the same time the echo and model of something other than itself.'

What is that something else that music refers to? I would like to suggest that the 'something else' that one kind of music - World Music - refers to is a sociological condition that goes by the name of 'global post modernity'. What is the global postmodern? There are two primary referents through which World Music reflects the idea of the global postmodern. The first is the idea of music as a 'structuration of global space' into the constitutive elements that go by terms such as local, national, regional, global and so forth. World Music, like all music, does not then simply provide a marker in pre-structured social space, but the means by which this can space can be transformed...music is socially meaningful, not entirely, but largely because it provides means by which people recognize identities and places, and the boundaries which separate them' (Stokes, 1994: 4-5). Secondly, World Music acts as a 'marker of identity' in the global structuration of space. Identity and its imbrication 
in power relations is a defining element in postmodernism - and is usually referred to by putting the two ideas together in the term 'identity politics' (where one's identity is more a product of social circumstance than individual will). Music, like other media forms, is a key element in how identity politics is mobilized in a culture. Discussing identity politics and gender, Stokes (1994:22) suggests that music is a key element in how boundaries which separate male and female are naturalised: 'It is as natural that men will make better trumpeters than women as it is natural that women make better harpists. Musical performance is often the principal means by which appropriate gender behavior is taught and socialized.'

Combing the two elements (global structuration of space and identity politics), Erlmann (1996:468) suggests: 'World Music is a new aesthetic form of the global imagination, an emergent way of capturing the present historical moment and the total reconfiguration of space and cultural identity characterizing societies around the globe.' Following up on Erlmann's (1996:481) proposal that 'an aesthetic theory of music in the global age...should examine the ways in which World Music constructs the experience of global communication through symbolic means' and Jensen's (2002:195) idea of music criticism 'as a form of cultural and social criticism... where talking and thinking about music, is a way of talking and thinking about (global) modernity', I suggest in this essay that a theory of the global postmodern focused on World Music be centred on its focal constitutive discourse - that of 'authenticity'.

To begin with, what is World Music? While some like Bohlman (2002:xi) argue that there is 'ample justification to call just about anything World Music', 'World Music' as a category was generated in the industrialised music markets of the developed world. In the introduction to World music: the rough guide (1999:1) editors Broughton, Ellingham and Trillo outline that:

'the name was dreamed up in 1987 by the heads of a number of small London-based record labels who found their releases from African, Latin American and other international stars were not finding rack space because record stores had no obvious place to put them. And so the World Music tag was hit upon, initially as a month-long marketing campaign to impress on the music shops, the critics and the buyers that there were sounds worth listening to. The name stuck, however, and was swiftly adopted at record stores and festivals, in magazines and books, on both sides of the Atlantic'.

There are some key issues that emerge for international musicians when working under the label 'World Music'. Their music must be seen as 'exotic, different, fresh... and (they are) categorized by their ethnicity rather than music' (Taylor, 1979:17). Discursively, too, it can be argued that the music reiterates 'old sensibilities about others and their cultures. Several common strands emerge: rejuvenation, novelty, authenticity, originality, the "real” and the spiritual' (Taylor, 1997:19).

Taylor (1977:21) suggests that 'authenticity' in World Music usually refers to two things: a 'cultural-ethnographic accuracy' (where the music speaks from a specific cultural/ local/national space) and his/her identity politics - what he calls the singers 'positionality' as a racialised, ethnicised, subaltern and pre-modern subject. Both these elements are combined with a psychosocial vision of personal performance where 'sincerity or fidelity to a true self' and 'credibility, sincerity and a commitment to one's art' are fused (Taylor, 1997:21). He adds that such a model of authenticity is shot through with issues of unequal discursive power and intent: 'These authenticities have at bottom an assumption about an essentialized, real, actual essence...the West, while it views its citizens as occupying many different subject positions, allows "natives" only one, and its whatever the West wants at any particular moment. So constructions of natives by music 
fans at the metropoles constantly demand that these natives be pre-modern, untainted, and thus musically the same as they ever were' (Taylor, 1997:21) Listeners of World Music, he concludes, 'consume some discernable connection to the timeless, the ancient, the primal, the pure, the chthonic; that is what they want to buy; since their own world is open seen as ephemeral, new, artificial and corrupt' (Taylor, 1997:26).

A key illustration of this process is the oft-cited case of Paul Simon's album Graceland which was seen as a process of 'rejuvenation' and the 'creative re-birth' of Paul Simon through his collaboration with South African artists (who came to represent an 'authentic' essentialised African voice). Many critics suggested that this was a form of sonic exploitation, if not evidence of contemporary cultural imperialism. 'Its hard to know if you are being attacked as an artist or as a person,' said Simon about the Graceland controversy, and this is the point: 'as a person he was resolutely anti-apartheid, as an artist, his western, voracious aesthetic allowed him to appropriate anything and do anything with it' (Taylor, 1997:22).

Is the 'authenticity' in World Music then merely a market tactic, a product of finding shelf space in western music stores? A brief detour through (cultural studies) theory is needed before I return to this question in the context of two African World Music stars. From a cultural studies perspective, 'popular music' texts can be analysed as institutionally produced commercial commodities that function as cultural artifacts inscribed with meanings which are then consumed and interpreted by fans and audiences. For Theodore Adorno the holistic, critical analysis of popular music as it moved through the circuits of production, textualisation and audience reception was central to understanding the politics of mass culture in modern capitalism. Popular music was a rationalised, standardised and pseudo-individualised artifact that produced rationalised and standardised responses of emotional sentimentality and false consciousness in the consuming public... within cultural studies, the theoretical counterpoint to Adorno has been the Gramscian emphasis on the resistance to hegemony among the 'people' and their capacity to produce their own meanings of popular texts and artifacts through ritual, re-contextualisation and alternate readings (Herman, Swiss \& Sloop, 1998:5).

The 'people' that a Gramscian reading refers to might include the musicians that produce World Music. McLeod (1999:146), for example, details the case for hip-hop culture that can be applied to World Music artists as well:

'The multiple invocations of authenticity made by hip-hop community members are a direct and conscious reaction to the threat of the assimilation and the colonalization of this selfidentified, resistive subculture. Authenticity claims are a way of establishing in-group/outgroup distinctions. Therefore, by invoking authenticity, one is affirming that, even though hip-hop music was the top-selling music format in 1998, hip-hop culture's core remains pure and relatively untouched by mainstream American culture. Hip-hop can balance large sales and mainstream success with a carefully constructed authentic self.'

A middle ground in this debate would assume that 'appropriation' is rarely just appropriation....any sort of cross-cultural musical interaction is an appropriation with multiple implications. According to Steven Feld, 'musical appropriation sings a doubline line with one voice. One of those lines is admiration, respect, the other is appropriation' (Taylor, 1997:40).

My analysis of World Music focused on Cesaria Evora and Ali Farka Toure, while informed by 
these wider sets of theoretical issues has a narrow focus - to examine the life histories and music of two individual musicians and track the specific ways in which the 'authentic' is used by World Music in the context of Africa.

\section{Two trajectories ${ }^{\text {iii }}$ of the 'authentic' in World Music/The Global Postmodern}

Cesaria Evora: Authenticity, Locality, and Gender:

Cesaria Evora is from the island of Cape Verde, a former Portuguese colony, off the coast of Senegal, a place that has lived on the crossroads of history. During the slave trade between the fourteenth and sixteenth century, it was a stopping point for the transport of thousands of African slaves to the America's and Europe. Portugal was an indifferent, abusive ruler - allowing the deaths of thousands as the Islands suffered from a series of famines and droughts. Life in the islands has always been difficult and hardscrabble - and its citizens have left in droves - to diasporic communities in Europe, South America and the United States. The Cape Verdan experience is often summarised as that of 'Sodade'. As the liner notes from a Putumayo album on Cape Verde puts it:

Isolated from the rest of the world, from their compatriots overseas, and even isolated by stretches of sea from their own countrymen on other islands, Cape Verdeans have developed a sense of pensive longing that permeates their cultural expressions. There is even a word that has come to describe this emotional state, one that has been immortalized in literature and song and has come to define the Cape Verdean character: Sodade (so-DAHJ). A sentiment of nostalgia, yearning and missing of home and beloved, 'sodade' describes a bittersweet feeling that has no direct English translation.

It is this history that speaks through the songs of Cesaria Evora songs - she sings in kriolu, a creole that blends old style Portuguese with West African languages. The instrument that defines much of her music is the cavaquinho. 'The cavaquinho is very much like a ukulele, with four strings, either steel or gut, that are tuned like the top four strings of a guitar' (Broughton, Ellingham \& Trillo, 1994:276). She sings a soulful genre, called the morna often compared to the blues but seen as quintessentially local - coming from the specificity of the Cape Verdean experience, an experience it seems mirrored in the personal story of Evora herself.

Cesaria Evora was born in 1941, on the Cape Verde island of Sao Vincente. Her father, who died when she was seven years old, was a cavaquinho player. One of five children, she was raised by her mother in abject poverty. Cesaria's early career was spent singing for her dinner - and to fight off depression. Occasional appearances on Radio Mindelo and in the numerous bars that dotted the port city of Mindelo allowed her to become well known in the neighboring islands as well. Never without her cigarettes, she sang mornas for aid workers, lawyers, traders, adventurers, chicken merchants, civil servants, until eventually she was recorded by a local retail businessman who sent the tape to Portugal to be made into a single.

Soon after, a local producer made another record - both records were complete failures. In 1975, Cape Verde became independent after a long struggle and the country, devastated by repeated droughts and no economic trade, sank into a depression - a condition reflected in Evora's life as well. She withdrew from singing for ten years, profoundly depressed and an alcoholic. Local accounts spoke of her wondering naked and wild through the streets of Mindelo in the grip of a 'fetico' (evil spell). 
At the start of the 1980's, an old friend found a place for her on a delegation of Cape Verdean

GMJ - AE Vol 3 (1)

singers for a tour of Lisbon. Singing in a restaurant, she met Jose da Silva who was to become her mentor and producer. He suggested a recording in Paris with leading Cape Verdean musicians - it was now 1987 and Cesaria Evora was 47 years old. Her first album, La diva aux pieds nus (The barefoot diva) met with limited success. A performance in Paris was reported on by the Le Monde paper that said, 'Cesaria Evora, a lively fifty year old, sings morna with mischievous devotion...[she] belongs to the world nobility of bar singers.' The legend of Cesaria Evora was beginning.

In 1992, a new album, Miss Perfumado, was released and went on to sell more than 300,000 copiesand was nominated for a Grammy in 1999 (after its American release). In 1997, she won the prestigious South African Kora Music award. In 2004, she won a Grammy for her album, Voz d'Amor. She has continued to perform and record ever since, with her tenth album, Rogomar (prayer for the sea) being released in 2007 (Graham, 2003; Coetzer, 1997; NPR, 2007; Plougastel, 2004).

I want to suggest that the sonic construct (music, songs, presence) of Evora draws on a specific discourse of authenticity - one located in a gendered account of African locality (the Cape Verdean experience) - across national and diasporic socio-spatial contexts. This account of locality provides the key to her appeal, her 'authenticity' as a World Musician. There are a number of intertwined elements.

Firstly, the circumstances of Evora's life and career mirror a wider problem about postmodernism and celebrity in an African context. Many singers and artists in the non-western world realize that they have little chance of being successful outside of a specific local cultural/regional space (like Africa or Latin America). The workings of global capital, they may surmise, are capricious, arbitrary and implausible - any kind of success is seen not as an entitlement but something both wondrous and implausible. As Joao Mendes, a Cape Verdean musician, puts it 'we were always outside the current. Just about every Cape Verdean we know is working in a factory, and we're doing this music' (Wald, 2007:50).

Evora presents in life and song, a reflexive engagement with the trajectory of her own life. The 'sound' of her music and her presence in performance which critics observe is often detached and sombre - an understanding of her circumstance, as not something given but a case of happenstance. While a reflexive engagement with career is a common element in western celebrity discourse often through close attention to the presentation of self in public forums (reflected iconically in the red carpet procession at award ceremonies) - what is different in the case of Evora is that it takes centre stage in her sonic construct - assumes a post-colonial value if you will - signaling a part of the world, where hunger can often mean death (rather than food stamps), where rootlessness is a given, life itself is not.

Secondly, Evora's 'text' speaks in concrete ways about the personal and sociological experience of being Cape Verdean (and African), a nation where most of its population has left for émigré communities in Europe and the United States. It is a national culture that is in a real sense, completely diasporic, where its relationship to 'Africa' is lived primarily in the imagination, fueled by both a sense of acute loss and profound belonging. Her best known songs reflect this concern directly. I will discuss two of them - Besame Mucho and Sodade. Besame Mucho (Kiss me many times) is the song most recognized (for non World Music fans). An old Mexican song, the key 
verses are:

GMJ - AE Vol 3 (1)

Besame, besame mucho, como si fuerda esta noche la utlima vez

Kiss me, kiss me many times, as if this night, were for the last time

Besame, besame mucho, que tengo miedo a perderte, perderte despues

Kiss me, kiss me many times. I am afraid I will lose you, lose you, later on

Piense que tal vez manana, yo ya estare lejos muy lejos de aqui

Thinking that perhaps by tomorrow, I'll already be far away, very far from here

It is paradoxical that a song from Mexico should be a standard bearer for the alienation of the Cape Verdean/African, but not completely surprising. The experience of exile, of leaving things behind is as much a fact of global culture as it is of the Cape Verdean/African experience. There is a central value accorded to departure itself ('leaving the past behind') but this value takes on an added meaning through the performative index of Evora. Watching her performance of Besame Mucho on video (ttp://au.youtube.com/watch? v=Esdl_3kKSBk), what stands out is her mode of address: her brow is written in perpetual anxiety, there is none of the practiced genuflections (of western artists) to audiences, little or no sense of her own presence on the stage. This is not the carefully calculated neglect of a Bob Dylan or the shy acknowledgment of mastery of Eric Clapton, but the expression of what is, undeniably, loss. Leaving, going far from home, being kissed for the last time, are elements of the common place. It is hard not to read into the text of Cesaria Evora's version of the song: a lament for the nation, a signature moment of collective dispersal with no return date - the nation in its moment of fragmentation holds no promise of a future - this experience is common to the emigration of populations from the third world to the first.

Evora's other signature song is Sodade, a famous morna. 'What the corrido is to Mexico or the tango to Argentina, the morna is to Cape Verde. This national song form is at least a century and a half old and is part of nearly every Cape Verdean band's repertoire. Mornas have minor key melodies and are slow, often with a beat similar to that of a Cuban habanera. But their lyrics are at the heart of the matter. The lyrics of a morna can stand alone as a poetic form. Lyrics usually speak of love and longing for one's distant cretcheu or beloved. The morna shares common and mournful roots in the Gulf of Guinea - slave plantation islands of Sao Tome and Principle - where a rhythm called lundum originated' (Broughton et.al, 1994:271). The translated lyrics to Sodade (alienation, loneliness, heartbreak) are:

Who showed you this far journey?

Who showed you this far journey?

This journey to Sao Tome

Sodade, Sodade, Sodade, for my land of Sao Nicolau

If you write to me, I'll write to you

If you forget me, I’ll forget you

Sodade, Sodade, Sodade for my land of Sao Nicolau

Until the day on which you return

By Luis Morais and Amandino Cabral from Miss Perfumado, translated by Caroline Shaw (Broughton, et al, 1994: 278).

Watching Evora sing Sodade on video is profoundly moving - in the live concert version I watched (http://au.youtube.com/watch?v=NbY7DBLw010) the song itself is book-ended by long acoustic 
interludes where Evora shuffles on the floor, sits smoking in a chair, and seems lost in contemplation of the very mood she is creating. It is a masterful rendition. The pacing, the movement, the punctuated equilibrium between the instruments and the singer are perfectly

GMJ - AE Vol 3 (1)

balanced. In sum, the discursive experience of alienation is mediated through her presence - which succeeds in doing the impossible: being simultaneously taciturn and effervescent, alone and commensual, emotional and detached.

Evora represents being in the moment and being disembodied better than any other musician I have seen. She makes the rendition of each line of the song, a thick metaphor for the lived experience of immigration. The first lines ('who showed you this far journey?') reflects the question asked by most migrants: what drew them away from their homes? A question that segments the many others that drive them all their lives: What did they leave behind? When can they return? What did they gain? What did they lose? She locates the wider question about belonging and migration to the specificities of the Cape Verdean/African experience with its references to the Island of Sao Nicolau. The other two verses ('If you write to me, I'll write to you. If you forget me, I'll forget you') are stirring for what they represent: a vision/experience of personal/national agency represented in the idea of writing and forgetting that most migrants feel. There is a dislocation, a coming apart of the old, and a sense of both arrival and departure that those leaving and those being left behind enter into. The possibility of becoming something else or somebody else.

Here the desire to connect depends on what point in the journey you are in; where relationships (may) continue with the act of renewal (writing) but the other event is much more likely 'if you forget me, I'll forget you.' For many modern migrants this experience is revisited throughout their lives: from the moment of departure, to periodic return, to death, at home or abroad. It is an experience that is constantly relieved through the rendition of music, literature, festivals and the texts of mediated experience (as in YouTube videos, for example). In sum, Sodade speaks to the complex set of emotions that make up the immigrant experience, a key recurring element of global post modernity.

Thirdly, Cesario Evora can be assessed as an element of the expression of African locality by her own self-definition as a musician. This refers primarily to her resistance to moving outside the musical ambit of Cape Verdean music. Her album Voz D’Amor (voice of love) has songs like Isolada, a morna that Plougastel (2004:1) says 'conveys all of the despondency in the world, the sorrows of caresses cut short and love lost, but also a great affection for an arid, rough country that forces many of its children into exile.' The song Jardim Prometido (promised garden) transforms a song about youth and rural life into an anthem full of hope for the future of a rainless country that will be forever verdant in the hearts of its people. The words become, 'in our dreams, this garden is not dead/the force of perseverance still tends it/Cape Verde is green in our hearts/full of love our hands will make the land grow green' (Plougastel, 2004:1). The song Monte Cara speaks of the mountain overlooking the port of Mindalo. Perhaps the most famous song from this album is Velocidade, a song written for Cesaria by a legendary Cape Verdean musician Luis Morais before his death in 2002. A simple song, it 'is a striking portrait of one of the pretty young girls to be admired on the terraces of Mindelo's café' (Plougastel, 2004:2). Similarly, Miss Perfumado, the album, is considered her most important work, as a rendition of classic Cape Verde morna songs including Sodade, Angola, Lua nha Testemunha and of course, Miss Perfumado. Her latest album Rogamar (Prayer to the sea) speaks of the presence of the sea, the love of the sea for the people of Cape Verde and the perils of the sea when crossing between the islands. 
In speaking from a place, a locality, Evora creates a marketing opportunity for herself, but equally importantly also mediates an understanding of African locality through her music. It needs to be emphasised that this measure of locality is produced relationally, through the active movement of people, of a culture in transition. People who stay in one place do not need to be reminded of

GMJ - AE Vol 3 (1)

locality, they embody it. Evora's music and songs, and her insistence on a tightly constructed narrative of locality (a landscape, a city, a bar, a certain rendition of authenticity of experience) is part of her magic - she constructs a landscape of belonging - and in doing so, she taps into the needs of the world marked by the postmodern condition, a condition defined quintessentially by migration (both local, national and global) and its resultant feelings of alienation, separation and personal/collective angst.

Finally, Evora represents her locality through a persona that reflects her identity as a poor African women and a Cape Verdean. Press reports continually speak of her as 'the barefoot diva' pointing to this as both a fact, born out of the experience of growing up poor and barefoot, and of her current decision, to use her barefoot presence, as a sign of support for the poor and disenfranchised women of her homeland.

The same themes are emergent in her responses to interviews by Western critics and scholars. The questions they ask are often constructed around the paradigms of celebrity, personality and promotion. Her responses are almost always about locality, authenticity and her identity as a Cape Verdean woman.

Here are some examples from an interview with Fred Bouchard. When asked, 'What singers or other musicians have influenced your style or evolution' she answered: 'Nobody really. I am singing the same Cape Verdean songs now that I was when I was 16. I can put some Spanish and Brazilian songs on my records, but that doesn't mean anything, because they are songs I like and understand. People like me best for my Cape Verdean music.' Her response is at odds, with the idea of personal development, of innovation, of individualism that firmly anchors corporate cultural expression. In speaking of continuity of performance, unchanged since 16, and presumably of a tradition much earlier, she constructs a presence that amplifies the need for tradition, a centre, in a fractured world. When she effaces Spanish and Brazilian influences in her songs, with 'but that doesn't mean anything,' it signals a clear intent to not problematise, to not deconstruct a narrative but to state, simply, that 'they are songs I like and understand,' suggesting a sense of her own agency: people like me best for my Cape Verdean music.

One exchange is particularly telling for the purpose at hand here: locality/authenticity/gender (and are being reproduced below in their entirety):

Q: Has fame and money affected you?

A: When I was singing in Cape Verde, I had no resources. Now, my career is bigger and I have more money. But that is all: my life is the same; I see the same people and sing the same songs. I think my singing hasn't changed.

Q: Do you live inside your songs, inhabit them?

A: You can say that I sing about myself and about others too. These things can happen to anyone. I am not singing about things that happen to me, but you might say they happened to you. I sing about love, immigration, and politics. It's a mix of day-to-day things. It's simple as that, nothing complicated. 
Q: What do you want to do next in your career?

A: When this tour ends, I'll go home to Sao Vincente and take rest for eight months. And then we'll see.

Q: What do you do at home?

A: I open my house to my friends and neighbors and visitors from abroad. I garden and I

GMJ - AE Vol 3 (1)

cook. You can come and visit if you like.

(Bouchard, 2000:52-54).

Her response to the first question is predicated around the key rubrics of performance and lived experience - in each case, she does not reach out to a rhetoric of excellence or effect but of personal intimacy and local 'embededness', especially around interaction and relationships. More crucially, she does not see her performativity to have changed and developed along new lines that often accompany ideas about impact that are central in the star's relationship to celebrity. This is at the heart of her authenticity, a sense of unchanged tradition, her feet (barefoot) grounded in the dirt.

Her response to the second question (about artist reflexivity) is astonishingly revealing. The question assumes a certain kind of response - about the process of creation, a finely developed sense of reflection and creation that most serious artists love to talk about, how they might as the question asks, 'inhabit' the song. Instead, what Evora gives is a response grounded in a postcolonial taciturnity - a direct and unproblematic assertion of the facts of life, which are about 'love, immigration and politics'. This is not merely a statement about the global postmodern condition one marked by movement (of money, people and ideas) but of the loss of agency as a woman (and the centering of the personal as political) and always, of an understanding (through moments of arrival and departure as also of loss and gain) of emotion, as a guiding principle in the life of individuals and communities. These facts of life, she asserts are 'day to day things' simple and uncomplicated. This too is at the heart of her presence as a signifier of authenticity. Her response to the third question (future plans) like the first one about fame is not what you expect from a celebrity within corporate media environments, who would use such a question to talk about their future projects, ('plug them so to speak') with a treatment of the themes they will address, or the personal space they will explore. Rather, Evora says she will rest up for six months and then decide. In response to the last question, Evora tells us she meets friends, gardens and cooks and opens her house to visitors - here too, the need for personal isolation that is a perquisite for celebrity life is missing, in favor of the authentic, grounded in the performance of a traditional gender politics cooking, gardening, meeting friends.

In sum, I would like to suggest that making sense of Evora as a signifier of global postmodernism implies an examination of authenticity through the range of ways in which she mobilises ideas about African locality. Evora mobilises through the work of her song/performance, an emotion central to immigration - a feeling of reaching back, of engaging with a tradition, of seeking texts that speak to this condition - and finding them in performances like those by Evora where they become coterminous with the artist - and understood through the kinesthetic appeal of their presence. It needs to be emphasized that this is not an understanding of tradition, grounded in sociological rules (around say food, religion or clothes) but an emotion, a feeling of being in the presence of an elder, somebody grounded in a different time and place, but able to through the aesthetics of expression to embody a collective loss, that is simultaneous Cape Verdean/African and universal in its address of the global postmodern condition. ${ }^{\text {iv }}$ 


\section{Ali Farka Toure: Authenticity, Locality and (African) Ethnicity}

I want to engage with Ali Farka Toure's life/work as embodying three elements of the discursive imprint of global postmodernism - a nuanced but emphatic assertion of African ethnicity - seen through three intertwined thematic elements - the construction of the 'rural'; a subaltern reading of (American) blues music; and finally, music as a negotiation of the religious/spiritual in the text of

GMJ - AE Vol 3 (1)

modernity. Each of these intertwined elements shape ideas about African locality and authenticity that he represents in World Music. First, a brief biography:

Ali Farka Touré was born in 1939, on the banks of the Niger River in northeastern Mali, near Timbuktu. His mother's nine previous children had all died in childhood, and the nickname 'Farka', or donkey, was given him as a form of protection, a symbol of endurance. At times he would wryly joke about this, telling one interviewer, 'Let me make one thing clear: I'm the donkey that nobody climbs on' (Winters, 2006).

Ali had no formal schooling and his childhood was shaped by life in a small farming community. He grew up entranced by the music played at spirit ceremonies in the villages along the banks of the Niger. He would sit and listen as musicians sang and played the favored instruments of the spirits: jurukele (single string guitar), n'jarka (single string violin) and $n^{\prime} g o n i$ (four string lute). His family did not consider music as an honorable occupation and the boy's interest was not encouraged. Ali was a fiercely independent boy and at the age of twelve built his first instrument, a jurukele (Duran World Circuit Biography).

He became known as the 'Bluesman of Africa' reflecting a style that combined elements of the American blues tradition and Arab-influenced Malian traditional music. After Mali's independence, he served as director of the Niafounke artistic troupe from 1962 to 1971 . With the troupe he performed for the first time in Europe, appearing at a 1968 international festival in Sofiya. He recorded extensively in France during the 1970s and began returning to his roots in the 1980s with a series of collaborative efforts, working with Taj Mahal on Source and Ry Cooderon Talking Timbuktu (Barz, 2007). He was never to make an album outside Africa again. He eleased Niafunké in 1999 and his collaboration with kora player Toumani Diabate, In the Heart of the Moon, in 2005 (Winters, 2006).

He won two Grammy's during his career, the only African artist to be so honored. He retired from his career as a musician shortly afterwards focusing on farming and eventually becoming the mayor of his town. In 2003, he participated in the documentary Feel Like Going Home. Directed by Martin Scorsese, the film traces the history of the blues from the banks of the Niger to the Mississippi Delta, and would bring Ali to an even wider audience. He worked on one final album, Savane, but did not live to the see its release. He died on March 7th 2006, succumbing to bone cancer. Ali was accorded a posthumous Commandeur de l'Ordre National du Mali (the country's highest honor) and a state funeral attended by all the country's senior politicians and major music stars as well as thousands of ordinary people (Duran, World Circuit Biography).

The 'rural' Ali first and foremost defined himself through the idiom of village and local African culture. This is not to suggest that he did not occupy an important place within the national iconography of Mali (he did, as can be attested by both the presence of the politicians at his funeral) and of the African continent more generally (as seen in the moniker - 'African bluesman'). Rather, it is the concreteness of his songs and his persistent efforts at self-definition within the regional context of his village and region that stands out. He chose to live in his village, for most of his life, 
placed farming and taking care of his town people (when he became Mayor) above music. He was often quoted as saying, 'for some people, Timbuktu is a place at the end of nowhere, but that's not true, I'm from Timbuktu, and I can tell you that it's right in the centre of the world' (http://news.bbc.co.uk/go/pr/fr/-/2/hi/africa/4782176).

The 'rural' that Farka came to represent was the 'desert' - here the discursive imprint of the Sahara and West Africa, with its arid landscape dotted by mud mosques, colorfully decked camels, and

GMJ - AE Vol 3 (1)

nomads became fused with his music. Much of this fusion came from his involvement and development of a 'festival of the desert' (also known as the Essakane Music Festival) in his hometown of Niafunke. The festival was an old tradition, going back over a century, a gathering of the nomadic Turaeg for a festival that celebrated their culture and music. Ali Farka Toure was a central figure in the 'reimagination' of the modern version of this festival beginning in 2001. In 2003, the festival was filmed by a French documentary maker, Lionel Brouet, and included former Led Zeppelin singer Robert Plant, Ali Farka Toure, Tinariwen, Oumou Sangare, and many others. The documentary focused on both the acts and the history and modern reassembling on an old tradition. In the years to come, the festival has become a tourist destination for fans of World Music and afro-pop, and is seen as a continuing legacy of Ali Farka Toure.

I want to spend some time discussing the construct of this festival drawing on viewings of songs from the documentary and on on-line diaries and images of the festival by music journalists. The festival's website (http://www.festivalinthedesert.org/) outlines the self-reflexive intent - both political and cultural - that the festival attempts to achieve:

The Essakane Music festival was developed by a Tamashek (Touareg) association whose aim is to develop the region, hit on the idea of grafting the Festival onto the great traditional gatherings of the Tamashek people on a grand scale. For centuries these gatherings have provided an invaluable opportunity for the nomadic Tamasheks to meet and celebrate with various forms of Tamashek song, dance, poetry, ritual sword fighting, games, and other ancient cultural traditions. The association opened the event to the entire desert region, to the whole of Mali, and eventually to the world. The festival celebrates the 1996 'Flame of Peace', in which 3000 guns were publicly burned to signify the beginning of the reconciliation between the nomadic and sedentary communities of the southern Sahara.

Music Journalists and critics who have visited and reported from the concert usually frame the music through the prism of the desert and the local Tureg culture. Sean Barlow who reported on the festival in 2003 for a number of outlets (Afropop.com, NPR, CBC, allAfrica.com visitors, World Link TV) described the experience as follows:

Just getting to the festival was a three-day adventure. The first legs of the journey covered familiar air space: New York to Paris to the Malian capital Bamako to Timbuktu in the north of the country. But then we drove northwest of ancient Timbuktu in a caravan of 'quatrequatres' (4x4s) across the rolling desert terrain. No road, just a track in the beige sand that suddenly turned into a fine pearl white. We passed groups of blue-turbaned Tuareg men heading to the Festival on their sprightly camels. Those camels! What dandies decked out in their Tuareg leather finery! Every toubab ('white person) amongst us seemed to fall under their spell. We arrived a day early at the Festival in the Desert's magnificent site, spread over gleaming white sand dunes under a cobalt blue sky.... Camping out with the royalty of Malian music in the Sahara Desert north of Timbuktu under a sky full of blazing stars... meeting new artists from Mali, Mauritania, Niger and beyond... without a doubt, the third 
annual Festival was the most thrilling music festival experience of my life. Over the next four days, I would visit the tents of familiar and emerging artists to film and record their groups performing informal, acoustic sessions and to interview them. Whenever a group started to play for us, local kids would flock to the tent opening and watch intently. http://www.afropop.org/multi/feature/ID/193/Festival+in+the+Desert+2003:+Dispatch+1

Songs from the documentary simultaneously evoke both the rural and the process of cultural revival that the festival. In one remarkable clip (http://au.youtube.com/watch?v=bA_bM7abhg) Ali is

GMJ - AE Vol 3 (1)

tightly framed as he introduces the festival by smiling hugely into the camera and saying 'the festival was organized for the pleasure of those who had never heard the word, 'festival' - and they are very happy about it.' The crowd of listeners squat on the ground, laughing and singing along with Farka and the other musicians - a number of people stand and dance on the stage. There are critical diacritical markers of the local - African clothes, local instruments (calabash, njarka), and dance (a slow, controlled gyration with deft hand movements). One reviewer of the CD (from the documentary) suggests that:

Mr. Toure exhibits some serious guitar chops across a wide swath of tempos, rhythms and styles. Most important, his seemingly effortless yet complex guitar playing is employed over beautiful compositions, vocal melodies, percussion and singing. The first track, Goye Kur is a tour de force with ringing, fluid chorused guitar, a bright bold vocal chant and melody, rumbling and precise calabash percussion and a haunting njarka line that anchors the whole shabang (Douglas Watkins, wwwhttp://www.amazon.com/Source-Ali-FarkaTouré/dp/B000000628).

It is a performance that evokes specific ideas about the nature of African music, one which is centrally located within a local culture but reaches out towards a global humanism, a discourse that often accompanies ideas about Africa as 'original home of humanity'. Agawu's (2003: xi) general analysis about African music is appropriate for what Ali's music came to stand for:

What is African music? It is communal and inviting, drawing in a range of consumers young and old, skilled and unskilled. It allows for the spontaneous and authentic expression of emotion. It is integrated with social life rather than set apart, natural rather than artificial, and deeply human in its material significance. Its themes are topical and sharp contemporary relevance, sometimes humorous and satirical, sometimes sad and affecting, often profound.

Ali's close ties to the rural land led him to turn down very lucrative offers to perform overseas. He remained uncompromisingly wedded to his traditional music, refusing to 'go commercial'. He invested in the development and innovation of local languages and showed an understanding that language and politics were deeply intertwined. During the 1990s rebellion by the Tuareg people of northern Mali, he was seen as a peacemaker singing in all of the region's languages - Songhai, Fulani and the Tuareg's Tamashek. He pioneered and perfected the adaptation of Sonrai, Peul and Tamascheq musical singing styles to the guitar. His songs celebrated both universal themes (love, friendship, peace) and specific to the village where he was born and raised: they spoke of the land, the spirits, and the river. When he was awarded his first Grammy, he refused to come to the United States for the ceremony, saying: "I don't know what a Grammy means but if someone has something for me, they can come and give it to me here in Niafunké, where I was singing when nobody knew me' (Winters, 2006).

African Bluesman: Ali's relationship with American Blues was a source of considerable ambivalence to him. 'The Times of London, in its obituary, noted that he didn't imitate the work of blues and soul giants like John Lee Hooker and Otis Redding, but rather 'claimed to recognize African roots (in those forms) and derived confidence and affirmation of his own art from the fact.' 
Certainly his international fame, which coincided with a growing Western interest in 'World Music', led to such comparisons and to the 'bluesman moniker' (Winters, 2006).

Touré was hailed as the Malian bluesman', and for a time seemed pleased at the comparison, but as the years passed he found the simplistic labeling an annoyance. 'The journalists always ask me the same questions,' he would say. 'They always want to know about blues. I say, the word "blues" means nothing to me. I do not know blues, I know the African tradition. The music that you call

GMJ - AE Vol 3 (1)

blues, I can call by its proper name. I can call it agnani, I can call it djaba. I can call it amandrai or amakari, the music played on the indigenous guitar, the one-string or the three-string. I can also call it kakamba. There are many names for this legendary art. I respect [Hooker] and appreciate his genius as the translator of African music in the United States, but my music is the roots and the trunk, and he is only the branches and the leaves' (Wald, 2006).

Nevertheless, he admired and was inspired by American music, just as American music had been enriched by the music of his homeland. He kept a picture of himself with Jimi Hendrix on display in his home, presumably from his 1960s international tours with a cultural group from Niafunké (Winters, 2006). Toure's music falls into a stream-of-consciousness groove, deftly employing repetition and chanting over a lilting beat. The mournful singing and string bending betrays his collection of American blues and soul cassettes (traces of Otis Redding, Lightnin' Hopkins, John Lee Hooker and others abound). But the Western influences seem but one guidepost, rather than a starting point, for Toure's deeply rooted, spiritual music. Not so much spiritual in the conventional sense, but more in worship of family, heritage, hard work and struggles on the land that nurtures (McCord, 2005).

What stands out is not just the terms of the post-modern encounter that Ali negotiates in his rendition of the blues, but his remarkable accuracy in reading it, as a text about subalternity, focused equally on the cultural/economic 'ghettoization' of the African-American experience and on his own mission, as the act of recovery, of an art form and the identity politics it represented. In this, Ali is perhaps unique, in understanding and assessing the ideological import of the Blues, across both sides of the Atlantic. In an interview (http://au.youtube.com/watch?v=y5Nem-PNHLY) Ali sits under the shade of tree, harmonizing with a visiting African blues musician. He provides a very personal vision of the work of global music, one marked by the burden of history and (simultaneously) a global humanism:

Blacks left (for the United States) with their culture, but the biography, the ethnicity, the legends they did lose. Still their music is African. Whether in the United States or in Mali, I think that there are only cities and distances separating us but our souls, our spirits are the same, there is no difference. There is no difference at all. I have never felt it. I feel sorry, why? Because they are people who should be united. The first time I heard John Lee Hooker, I said, I heard his music but I said, I don’t understand this music - where did they come up with this? This is something that belongs to us, but its different - because he had to play to make a living. Otherwise this music is not made for whisky, or for scotch, or for beer. When a black American comes to Africa, he should not feel like a foreigner, because he has left his home. It's your territory. It's your navel.

Religion/Spiritualism: Finally, Ali spoke from a very specific religious/spiritual space: a hybrid form of Islam and Animism. In today's atmosphere of the 'war on terrorism' and the radicalization of Islam in many parts of the world, Ali's work and life attests to a syncretic African Muslim identity. As a child, he was seen as a 'child of the river'. This had a very specific powerful connotation: 
In Niafunke, as in most of Mali, the dominant religion was Islam and Ali was a devout Muslim. But in this part of the world Islam co-exists with a much older indigenous belief system connected with the mysterious power of the Niger. People believe that under the water there is a whole world of spirits called Ghimbala - male and female djinns with their own character and history and symbolic colors and ritual object; all this is vividly portrayed in the local mythology. These djinns control both the spiritual and temporal world. When the harmony of these two worlds go wrong, as it inevitably happens in this harsh, unpredictable

GMJ - AE Vol 3 (1)

climate, when there are unexplained illnesses or sudden natural disasters, then people get together to hold spirit ceremonies, in which music and dance are the central activity. Then thanks to music, spirits may accept the gifts, and if so, it is considered as an auspicious sign. Those who have the ability to communicate with the spirits are called 'children of the river.

Consequently, Ali's was intensely personal and spiritual, sacred and common at the same time. Though he won a Grammy this year for In the Heart of the Moon, an album of duets with Toumani Diabate, one of the masters of Mali's griot, or court music, tradition, he always distanced his own style from that of the griots. Theirs was made for money, he would explain, while his was a way of communicating with the genii or spirits: 'It speaks of cows, of greenery, of a man with his animals in the wilderness who hears certain sounds which do not come from the animals, but from nature. It speaks of love and of harmony in the family. All of these tunes have their words, their legend, and their story.'

In the end, he would turn away from his music when he felt it was getting too commercialised and instead focus on what he thought mattered: the land, the village, the local. In 2004, Touré became Niafunke's mayor:

Children flocked around him, [and] locals looked to him for leadership, advice, employment and financial support.... He committed himself to community and commercial development, and even played shows in France to fund initiatives to develop the town. A reasonably well-off man, he nonetheless spoke of poverty (pauvreté) as being the true path to happiness, meaning that one should not waste energy on material wants, but live simply. It is all right to have means, but use them wisely and help others. He exemplified this philosophy with his life (adapted from Duran, 2004).

In sum, we may see the life/work of Ali, as imbued with specific notions African authenticity - his sonic construct tied to a specific identity politics - based on patrimony, religion and a hybrid Islam on one hand, and a humanistic, environmentally centered (almost Gandhian politics) of space on the other. In between these discourses lies his (uneasy) but key alliance with American blues. ${ }^{\mathrm{v}}$

Understanding his place as a global music text is important precisely because he exemplifies the kinds of ruptures and absences that mark the working of a global postmodernism: a process neither usefully tracked with accounts of cultural homogenization nor of cultural bricolage. Rather his work represents an act of strategic imagination and cultural recovery that is often an ignored part of the work of global postmodernism.

\section{Conclusion}

To summarise, the two artists discussed here represent different trajectories in how the discursive construct of African 'authenticity' is played out in World Music (as illustrative of the wider working of global postmodernism). Each singer represents authenticity through a rendition of African 'locality' through mobilisation of themes of gender and performativity (Cesaria Evora) and 
rural/religion (Ali Farka Toure). I would like to suggests that a wider theory of global postmodernism must take account of three (interrelated) ideas about the 'authentic' that are emergent from a consideration of these two artists.

Firstly, the 'authentic' is not a monolithic construct, made up of a fixed set of cultural binaries of west/rest; self/other; modern/traditional, but are mobilized through a specific account of locality, such as Africa. Rather than mere agents of global capitalism or indigenous elites, these artists assert that the idea of authenticity must engage with the sheer empirically of the local as an element of global postmodernism. The local, as I have suggested, speaks in/through many contexts (gender,

GMJ - AE Vol 3 (1)

religion etc) and it is its sheer imbrication within and across these multiple areas that allows for its viability in the modern world. To put it another way, the global (postmodern) cannot exist without the local.

Secondly, the 'authentic' is not a static sociological category but has an expressive element: manifest in the kinesthetic and psychological experience of listening to music. What connects both these artists is the sheer pleasure of watching/listening/experiencing their music. The voice and presence of Evora and Toure are eloquent testimony to the return of the 'authentic' in an age of global mass production. The very personal and emotive engagement that draws its fans to World Music is at the heart of its appeal. To put this more speculatively, the centering of pleasure is a defining element of 'authenticity' in World Music.

Finally, the 'authentic' in the work of World Music allows for a contextual, localized and transcultural account of identity in the modern world. In the end, what connects both these artists is the cultural work of performing (African) identity. If global postmodernism is the discursive centering and movement of identity politics, then these artists represent - through the biographical and discursive imprint of their music - the placement of 'Identity' as the central site for the logic of global post modernity.

\footnotetext{
i Peter Gabriel summarises these popular discourses: 'There are two jobs to be done,' he says. 'One is to protect and preserve the seed stock as wide and varied a base as you can keep alive. The other is to try out as many hybrid possibilities as you can that will give you the most vibrant, pulsating, new life forms' (Taylor,1997;41). Bohlman (2002: xii) put this more formally: 'There are two contradictory ways in which World Music is understood today... For many, World Music represents much that is right in the world, indeed, the very possibility that music and musicmaking bring people together... There's also the darker side to World Music. World Music can raise fears that we are losing much that is close to home. Its homogenizing effect threatens village practices as it privileges the spaces of the global village. Its dissemination across the globe depends on the appropriation of transnational recording companies, whose primary interests are to exploit cultural resources. Fusion and border-crossing may enrich some World-Music styles, but they impoverish others.'
}

ii International Communication scholars have not systematically addressed World Music. For a broad accounting of the different artists and music that comprise World Music see Wald (2007), Bordowitz (2004) and the excellent but now dated World Music: The Rough Guide (Broughteon, et al, 1999). For a broad theoretical accounting of the World Music see Taylor (1997), Tenzer (1996), Feld (1994, 2000), Keil and Feld (1994), Nettl, Turnino, Wong, Capwell \& Bohlman (2004) and Bohlman (2002). For studies on World Music within the field of cultural studies, see Barrett (1996), Goodwin and Gore (1990), Erlmann (1996) For studies within the field of International Communication, see Colista and Leshner’s (1998), Garafalo (1993), Laing (1986) and Roberts (1992).

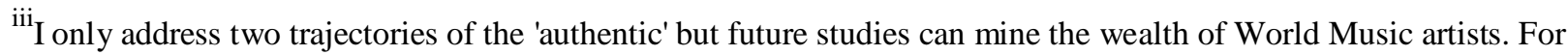
example, in the African context studies could examine post-colonial identity and gender using women singers such as Umm Kalthum (Egypt), Hadia Talsam (Egypt), DjurDjur (Algeria) and Angeline Kidjo (Benin) as case studies.

${ }^{i v}$ This is not to say that this loss is felt the same way by those in West. For the largely white audiences that pack her concerts, looking for the smallest sign that she recognizes their need (for involvement with the audience) is part of her 
appeal. In a more critical sense, while they are participating in the discourse of the local and the authentic, there is a crucial difference. It is the pleasure of diasporic dislocation, without any of its real-life effects or constraints. Exile, becomes a commodity for consumption, much like youth angst or black disenfranchisement.

${ }^{\mathrm{v}}$ The desire of World Music fans to see Ali as a "Mali Bluesman" can be seen as part of a wider marketing/discursive strategy that has a long history. As Wald (2007) puts it, "the World Music boom has to a great extent been sparked by the quest of western musicians to reconnect their music with its roots, and for a hundred years quests for the root of pop have tended to lead back to Africa. Ragtime, Jazz, blues, rock, salsa, reggae, hip-hop - the rhythms of Africa have been the engine of virtually all modern international styles (1).

\begin{abstract}
About the author:
Anandam Kavoor is a Professor in the Grady College of Journalism and Mass Communication at the University of Georgia, Athens, Georgia, USA. He is the author of Thinking Television (Oxford: Peter Lang) and the co-editor of four books on global communication and culture. He has been a consultant to CNN International, NewsCorporation and the Discovery Channel.
\end{abstract}

\title{
Contact Information:
}

Room 101a, Grady College of Journalism and Mass Communication, The University of Georgia, Athens, GA 30602, USA.

akavoori@gmail.com; 706-542-4971

\section{References}

Agawu, K. (2003). Representing African music. London: Routledge.

Aubert, L. (2007). The music of the other: New challenges for ethnomusicology in a global age. Aldershot, UK: Ashgate.

Barrett, J. (1996). World music, nation and postcolonialism. Cultural Studies. 10(2):237-247.

Bohlman, P.V. (2002). World music: A very short introduction. Oxford: Oxford University Press.

Bordowitz, H. (2004). Noise of the world: Non-western musicians in their own words. Brooklyn, NY: Soft Skull Press.

Bouchard, F. (2000). Genuine Cape Verdean Soul (Interview with Cesaria Evora). Down Beat: Jazz, Blues and Beyond. 67:2:52-53.

Broughton, S., Ellingham, M., \& Trillo, R. (Eds.). (1999). World music: The rough guide. London: Rough Guides.

Coetzer, D. (1997). Evora top winner at S. Africa’s Kora’s. Billboard, Oct 25, 1997, pg. 60, 83.

Colista, C., \& Leshner, G. (1998). Traveling music: Following the path of music through the global market. Critical Studies in Mass Communication. 15, 181-194.

Duran, L (2004). Ali Farka Toure (World Circuit Biography). http://malimusic.com/cat/cata/aft/aftbioa.html.

Erlmann, V. (1996). The aesthetics of the global imagination: Reflections on world music in the 1990s. Public Culture. 8:467- 487. 
Feld, S. (1994). Notes on 'world beat'. In Keil, C. \& Feld, S. (Eds.). Music grooves. Chicago: University of Chicago Press.

Feld, S. (2000). A sweet lullaby for world music. Public Culture, 12(1):145-171.

Garofalo, R. 1993. Whose world, what beat: The transnational music industry, identity, and cultural imperialism. The World of Music, 35(2):16-32.

Goodwin, A., \& Gore, J. (1990). World beat and the cultural imperialism debate. Socialist Review. 20(3), 63-80.

Graham, E. (2003). The international country of Cesaria Evora. magazine.net/php/modules/107-.

Herman, A., Swiss, T., and Sloop, J. (1998). Mapping the beat: Spaces of noise and places of music. In Herman,A., Swiss, T., and Sloop, J. (Eds). Mapping the beat: popular music and contemporary theory. Oxford: Blackwell, pp. 3-30.

Jensen, J. (2002). Taking Country Music Seriously: Coverage of the 1990s boom. In S. Jones. (Ed.), Pop music and the press (pp.183-201) Philadelphia: Temple University Press.

Keil, C., \& Feld, S. (1994). Music grooves. Chicago: University of Chicago Press.

Laing, D. (1986). The music industry and the 'cultural imperialism thesis. Media, Culture and Society. 8:331-41.

McCord, J. (2005). Ali Farka Toure: Red and Green. (World Circuit Review) mahler publications division. http://gateway.proquest.com (Review of Red and Green).

NPR (2007). Cesaria Evora: At home on the road, All Things Considered (Radio Show). http://npr.org/templates/story/story11426375.

Stokes, M. (1994). Ethnicity, Identity and Music: The musical construction of place. Oxford: Berg. Wald, E. (2007) Global Minstrels. London: Routledge. 